\title{
$ノ-卜$
}

\section{リポソームに内封したペルオキシダーゼを触媒に用いる フルオレセイン化学発光による過酸化水素の定量}

\author{
上舘 民夫 ${ }^{\circledR 1}$ ，石田 良樹 ${ }^{1}$ ，谷 博 ${ }^{1}{ }^{1}$ ，石田 晃彦 ${ }^{1}$
}

\author{
Determination of Hydrogen Peroxide by Fluorescein \\ Chemiluminescence Catalyzed with \\ Horseradish Peroxidase Encapsulated in Liposome
}

\begin{abstract}
Tamio KAmidate ${ }^{1}$, Yoshiki Ishida ${ }^{1}$, Hirofumi TANI ${ }^{1}$ and Akihiko IshidA ${ }^{1}$
${ }^{1}$ Division of Molecular Chemistry, Graduate School of Engineering, Hokkaido University, Kita 13-Nishi 8, Kitaku, Sapporo-shi, Hokkaido 060-8628
\end{abstract}

(Received 14 December 2004, Accepted 17 March 2005)

\begin{abstract}
Fluorescein (FL) and $\mathrm{H}_{2} \mathrm{O}_{2}$ rapidly permeated into the inner phase of liposome which trapped horseradish peroxidase (HRP), to initiate HRP-catalyzed FL chemiluminescence (CL) with $\mathrm{H}_{2} \mathrm{O}_{2}$. The CL intensity was dependent on the concentration of $\mathrm{H}_{2} \mathrm{O}_{2}$. The optimum conditions of charge-type, composition and diameter of liposome in the assay of $\mathrm{H}_{2} \mathrm{O}_{2}$ were determined by measuring the CL intensity, to be maximal under optimum conditions. Anionic liposome containing phosphatidylcholine, dimyristoyl-glycero-phosphocholine and cholesterol (Chol) was effective for enhancing the CL intensity and stability of liposome. The CL intensity decreased with an increase in the content of Chol in liposome. The optimal content of Chol was thus determined to be $10 \mathrm{~mol} \%$. The effect of the liposome size on the CL intensity was examined by preparing liposomes with a different diameter. The CL intensity increased with an increase in the diameter of liposome. The optimal diameter of liposome was thus determined to be $1000 \mathrm{~nm}$. The logarithmic calibration curve of $\mathrm{H}_{2} \mathrm{O}_{2}$ was linear over the range from the detection limit of $4.0 \times 10^{-8} \mathrm{M}$ up to $1.0 \times 10^{-5} \mathrm{M}$. When HRP trapped in liposome was used as a catalyst, the CL intensity was greater than that observed by using HRP dissolved in

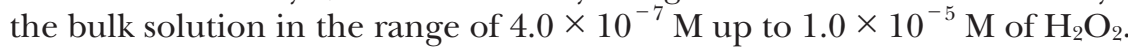

Keywords : chemiluminescence; liposome; peroxidase; hydrogen peroxide; fluoresein.

\section{1 緒 言}

リン脂質二分子膜から成るリポソームは数十〜数百 $\mathrm{nm}$ の粒子径を有するナノ閉鎖小胞であり，その内水相に多数 の分子を封入できる。そこで，近年，酵素を内封したリポ ソームを調製し，その内水相を酵素反応の場に応用する研 究が多数報告されている1). Hill らはグルコースオキシダ ーゼ（GOD）を内封したリポソームの外水相にグルコー スを加え, 過酸化水素 $\left(\mathrm{H}_{2} \mathrm{O}_{2}\right)$ への変換速度を測定し,

${ }^{1}$ 北海道大学大学院工学研究科分子化学専攻: 060-8628 北海道 札棍市北区北 13 条西 8 丁目
リポソーム内水相とバルク溶液における GOD の酵素活性 の比較を行っている ${ }^{2)}$. また， $\alpha$-キモトリプシンを内封し たリポソームの外水相に基質を加え, 基質の分解速度から リポソーム内水相における酵素反応の速度論的な解析が行 われている3). しかしながら，これまでに多くの酵素反応 が分析法に利用されているが，それらの酵素反応をリポソ 一ムの内水相で行う試みはなされていない.

そこで, 著者らはイムノアッセイにおいて広く標識体と して用いられている西洋わさび由来のペルオキシダーゼ (horseradish peroxidase, HRP) を封入したリポソームを 調製し,リポソーム内の HRP を直接的に化学発光 (CL) 
法で検出することを試みた ${ }^{4)}$. その結果， CL 試薬である フルオレセイン（FL）と $\mathrm{H}_{2} \mathrm{O}_{2}$ がリポソーム膜を迅速に透 過し, リポソームの内水相で HRP を触媒とする FL-CL 反 応が進行することを見いだし，HRPの検出に応用した。

一方, 臨床診断的に重要な生体分子の定量において, 酵 素反応を用いて生体分子を $\mathrm{H}_{2} \mathrm{O}_{2}$ に変換後, 生成した $\mathrm{H}_{2} \mathrm{O}_{2}$ の測定から間接的に生体分子の定量が行われてい る.そこで本研究では, リポソームの微小空間における HRP を触媒とする FL-CL 反応を $\mathrm{H}_{2} \mathrm{O}_{2}$ の定量に応用する ため, $\mathrm{H}_{2} \mathrm{O}_{2}$ の定量に適した HRP 内封リポソームの調製 条件について検討を行った。

\section{2 実験}

\section{$2 \cdot 1$ 試 薬}

$\mathrm{CL}$ 反応にはウラニン（FL のナトリウム塩）, $\mathrm{H}_{2} \mathrm{O}_{2}$ 及び HRP (生化学用) を使用した. リポソームの調製にはホ スファチジルコリン (PC), ジミリストイルホスファチジ ルグリセロール（DMPG）及びジステアリルジメチルアン モニウムクロライド（DSDAC）及びコレステロール （Chol）を用いた. pH 緩衝溶液の 3-モルフォリノプロパ ンスルホン酸（MOPS）は同仁化学研究所製を使用した. ポリエチレングリコールモノ-p-イソオクチルフェニルエ ーテル（トリトン X-100） はナカライテスク製液体シンチ レーション用を使用した。

\section{$2 \cdot 2$ 装 置}

CL の測定には東北電子産業製の TD-3A を使用した。

リポソーム調製器は AVESTIN 製の LiposoFast ${ }^{\mathrm{TM}}$-BASIC を使用した。フィルターは AVESTIN 製ポリカーボネート

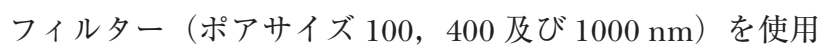
した。

誘導結合プラズマ（ICP）発光分析装置には島津製 ICPS-1000IV，超音波ネブライザーには同社製 UAG-1，オ ートサンプラーには同社製 AS-6 を用いた。

\section{$2 \cdot 3$ 操 作}

2・3・1 HRP 内封リポソームの調製アニオン性リポ ソームの調製にはクロロホルムに PC, DMPG 及び Chol を溶解したものを母液として使用した。 カチオン性リポソ ームの調製にはクロロホルムに PC, DSDAC 及び Chol を 溶解したものを母液として使用した。脂質の全量は 40 $\mu \mathrm{mol} \mathrm{ml} \mathrm{m}^{-1}$ とした. いずれの母液も $-20^{\circ} \mathrm{C}$ で保存した. クロロホルムは使用前にソニケーターを用いて十分に脱気 を行った。

HRP 内封リポソームは前報に準じ, 押し出し法により リポソーム (vesicles by an extrusion techniqwue, VET) を調製した ${ }^{5)}$ 。なお，ポアサイズ $1000 \mathrm{~nm}$ のフィルターで
処理したリポソームを $\mathrm{VET}_{1000}$ と表記する．また，HRP 内 封リポソームと未封入の HRP の分離も前報に準じて行っ た

$2 \cdot 3 \cdot 2 \mathrm{H}_{2} \mathrm{O}_{2}$ の $\mathrm{CL}$ 測定 $\quad \mathrm{CL}$ の測定は以下の手順で 行った。ガラスキュベットに HRP 内封リポソーム溶液 $500 \mu \mathrm{l}$ 及び FL 溶液 $500 \mu \mathrm{l}$ を入れた。次にインジェクター を用いて $\mathrm{H}_{2} \mathrm{O}_{2}$ 溶液を $500 \mu \mathrm{l}$ 注入して CL 反応を開始し た。CL応答曲線は記録計で記録した。なお，HRPを MOPS 緩衝生理食塩水（以下，緩衝溶液）に溶解した HRP 標準溶液を用いる場合には，HRP 内封リポソーム溶 液の代わりに HRP 標準溶液 $500 \mu \mathrm{l}$ を用いた。添加する FL 濃度は $4.0 \times 10^{-4} \mathrm{M}$ とした ${ }^{4)}$ 。なお，本文中の試薬濃 度は初濃度で表示した。

\section{3 結果及び考察}

\section{3・1 CL 応答に及ぼすリポソームの表面電荷の影響}

HRP をリポソームに内封する際, 表面電荷がカチオン 性及びアニオン性のリポソームを用いることができる。そ こで，PC，DMPG 及び Chol のモル比が $7: 1: 2$ になるよ うにクロロホルムに溶解し，アニオン性の HRP 内封リポ ソームを調製した。また，PC，DSDAC及び Chol のモル 比が $7: 1: 2$ になるようにクロロホルムに溶解し, カチオ ン性の HRP 内封リポソームを調製した。また，アニオン 性リポソームをトリトン X-100 で溶解後のバルク溶液中 の HRP 濃度 $\left(1.6 \times 10^{-6} \mathrm{M}\right)$ に等しい濃度の HRP 緩衝 溶液に溶解した HRP 標準溶液も調製した。

それぞれの溶液に $4.0 \times 10^{-4} \mathrm{M} \mathrm{FL}$ 及び $4.0 \times 10^{-5} \mathrm{M}$ $\mathrm{H}_{2} \mathrm{O}_{2}$ 溶液を加え, CL 応答曲線を測定した. Fig. 1 の CL 応答曲線から, FL 及び $\mathrm{H}_{2} \mathrm{O}_{2}$ が迅速にリポソーム膜を透 過することが分かる. また, 最大の発光量を CL 強度とす ると, HRP 標準溶液の CL 強度と比較して, HRP 内封リ ポソームの内水相を反応場に用いたほうが CL 強度は著し く増大した.リポソーム内水相における CL反応において CL 強度が増大する原因として，以下の理由が考えられる。 いま，同一のモル数の HRP がバルク溶液に均一に分散し ている場合と, リポソームに封入されている場合を比較す ると，リポソーム内に封入されているほうが HRP 濃度は 局所的に増大する。また，HRP 濃度が高いほど CL 強度 は増大する ${ }^{4)}$. したがって, リポソーム内水相の CL 反応 における CL 強度の増大は, HRP の局在化による効果が 考えられる。また，そのほかにリポソーム内での HRP 活 性の向上あるいは発光化学種の蛍光量子収率の増大などが 考えられるが, 詳細については現在のところ不明である.

次に, カチオン性リポソームを用いたほうが CL 強度が 増大した原因として，以下の理由が考えられる．FLのモ ノアニオン化学種 $\left(\mathrm{FLH}^{-}\right)$からジアニオン化学種 $\left(\mathrm{FL}^{2-}\right)$ への酸解離定数 $\left(\mathrm{FLH}^{-} \mathrm{FL}^{2-}+\mathrm{H}^{+}\right)$は $\mathrm{p} K_{\mathrm{a}}=6.4$ である 

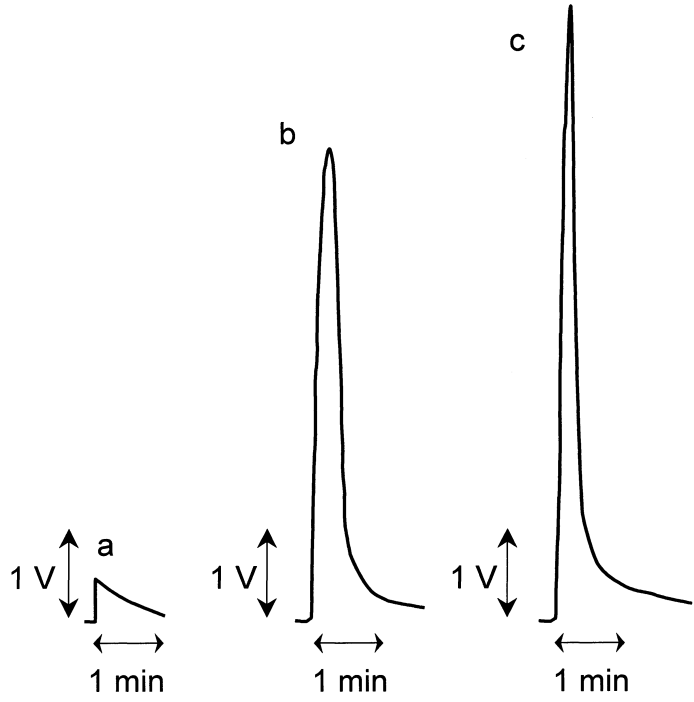

Fig. 1 Effect of charge-type of $\mathrm{VET}_{1000}$ on CL response curves observed in (a) HRP standard solution, (b) HRP-encapsulated anionic liposome suspensions and (c) HRP-encapsulated cationic liposome suspensions

ことから ${ }^{8)}, \mathrm{CL}$ 反応の $\mathrm{pH}$ 条件に扔いて, CL 反応に関与 するモノアニオン化学種が約 20\% 溶解していることにな る。したがって，カチオン性リポソームの表面に扔いて $\mathrm{FLH}^{-}$との間で静電的な相互作用が起こり, リポソーム表 面において $\mathrm{FLH}^{-}$濃度が増大し, $\mathrm{FLH}^{-}$の膜透過が促進さ れるために，アニオン性リポソームと比較して CL 強度が 増大したものと考えられる。

なお，カチオン性リポソームを用いた場合，アニオン性 リポソームを用いた場合より CL 強度は増大したが，調製 後約 2 日で沈殿を生じた。一方, アニオン性リポソーム は調製後 1 週間以上経過しても沈殿せず，保存安定性が よかった。したがって, 以降の実験ではアニオン性リポソ ームに HRP を内封することにした.

$3 \cdot 2 \mathrm{CL}$ 強度に及ぼすリポソーム中のコレステロール 含量の影響

Chol はリポソームの安定性を向上させることから，リ ポソームの膜構成成分として一般的に用いられている。一 方, Chol はリポソームの膜流動性にも影響を与えること が知られている。したがって, Chol 含量は FL 及び $\mathrm{H}_{2} \mathrm{O}_{2}$ の膜透過速度に影響を与え, その結果, CL 強度に影響を 及ぼすことが考えられる。そこで，CL強度に及ぼすリポ ソーム膜中の Chol 含量の影響を検討した. DMPGの組成 を 10\% 一定とし, PC 及び Chol のモル比を変化させるこ とにより，Chol 含量が 10〜 40\%の $\mathrm{VET}_{1000}$ を調製した. なお, Chol 含量が 10〜 40\% の範囲で HRP の保持効率は 30\%でほぼ一定であった（変動係数：4\%).

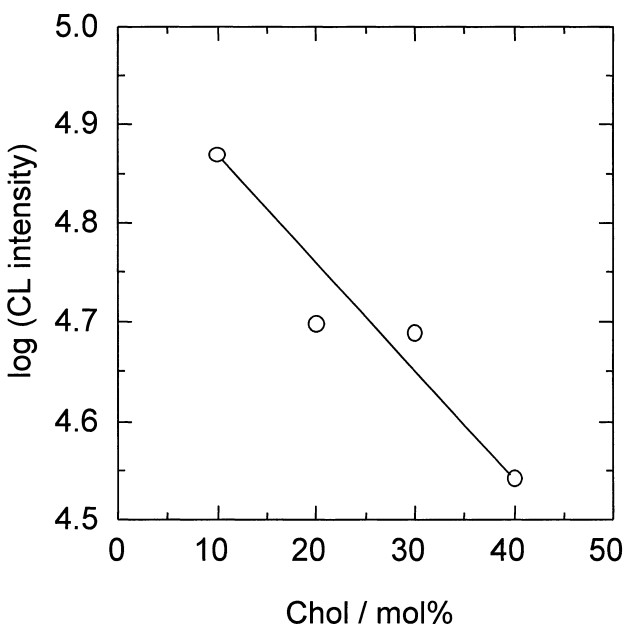

Fig. 2 Effect of cholesterol concentration on CL intensity

それぞれの Chol 含量の HRP 内封リポソーム溶液に, $4.0 \times 10^{-4} \mathrm{M} \mathrm{FL}$ 及び $4.0 \times 10^{-5} \mathrm{M} \mathrm{H}_{2} \mathrm{O}_{2}$ 溶液を加えて $\mathrm{CL}$ 応答曲線を測定した。Chol 含量が増大するに従って CL 応答速度は減少し, 発光量が CL 強度の半分の值までに減 衰する時間は Chol 含量が $40 \%$ の場合, $10 \%$ の場合と比 較して約 1.5 倍増大した。また, Fig. 2 に示すように, Chol 含量が増加するに従って CL 強度も減少した.

Chol 含量が増大するに従って CL 強度が減少する理由 は次のように説明される. Chol 含量が増大するに従って, リポソームの膜構成成分である PC 及び DMPG の炭化水 素鎖とChol との疎水性相互作用が増大する ${ }^{9)}$. その結果, 膜の流動性が低下して FL 及び $\mathrm{H}_{2} \mathrm{O}_{2}$ の膜透過速度が減少 し，そのため CL 強度が減少したと考えられる。

以上の結果から，アニオン性リポソームを調製する際の 最適な Chol 含量は $10 \%$ とし, PC, DMPG 及び Chol の モル比は $8: 1: 1$ とした.

\section{3・3 CL 強度に及ぼすリポソームサイズの影響}

粒子径が異なる $\mathrm{VET}_{100}, \mathrm{VET}_{400}$ 及び $\mathrm{VET}_{1000}$ を調製した。 PC, DMPG 及び Chol のモル比は 8:1:1 とした。なお, $\mathrm{VET}_{100}, \mathrm{VET}_{400}$ 及び $\mathrm{VET}_{1000}$ の HRP の保持効率はほぼ一 定（変動係数： 5.6\%）であった。

それぞれの HRP 内封リポソームを含む溶液に $4.0 \times$ $10^{-4} \mathrm{M} \mathrm{FL}$ 及び $4.0 \times 10^{-5} \mathrm{M} \mathrm{H}_{2} \mathrm{O}_{2}$ 溶液を加え, CL 応答曲 線を測定した. $\mathrm{VET}_{1000}$ と $\mathrm{VET}_{400}$ では $\mathrm{H}_{2} \mathrm{O}_{2}$ を注入後, 発 光量は数秒で最大となり, その後, 徐々に減少して約 90 秒ほどで CL 反応は完了した。一方， $\mathrm{VET}_{100}$ では $\mathrm{H}_{2} \mathrm{O}_{2}$ を 注入後, 発光量は約 30 秒で最大となり, その後徐々に減 少して, 約 3 分ほどで CL 反応は完了した. $\mathrm{VET}_{100}$ を用い たときの CL 強度に対する相対強度比は $\mathrm{VET}_{400}$ で 1.4 , $\mathrm{VET}_{1000}$ で 1.5 となり, リポソームサイズが大きくなるほ 
ど CL 強度は増大した。したがって， $\mathrm{VET}_{1000}$ を最適リポ ソームサイズとした.

リポソームサイズによって CL 強度が異なるのは, リポ ソームの直径が大きくなるほどリポソームの曲率が増大 し，リン脂質とコレステロールの疎水性相互作用が弱まる ため, FL あるいは $\mathrm{H}_{2} \mathrm{O}_{2}$ の膜透過性が増大したためと考 えられる。

\section{$3 \cdot 4 \quad \mathrm{H}_{2} \mathrm{O}_{2}$ の検量線の作成}

最適条件で調製した HRP 内封リポソームを用いて $\mathrm{H}_{2} \mathrm{O}_{2}$ の CL 応答曲線を測定し, $\log -\log$ プロットにより検 量線を作成した。定量下限の $4.0 \times 10^{-8} \mathrm{M}$ から $1.0 \times 10^{-5}$ $\mathrm{M}$ の範囲において, $\mathrm{H}_{2} \mathrm{O}_{2}$ 濃度と CL 強度との間に良好な 直線関係が得られた。なお, $\mathrm{H}_{2} \mathrm{O}_{2}$ を含まない空試験溶液 の CL 強度を測定し, その標準偏差の 3 倍の CL 強度を与 える $\mathrm{H}_{2} \mathrm{O}_{2}$ 濃度を定量下限とした. 検量線の回帰式は $y=$ $0.888 x+9.09$ ，相関係数は $r^{2}=0.990$ であった。各 $\mathrm{H}_{2} \mathrm{O}_{2}$ において 3 回の繰り返し測定を行い, $\mathrm{H}_{2} \mathrm{O}_{2}$ の全濃度範囲 における変動係数の平均は $6.5 \%$ であった。

次に, HRP 標準溶液を用いて $\mathrm{H}_{2} \mathrm{O}_{2}$ の検量線を作成し た. $\log -\log$ プロットにおいて, 定量下限の $4.0 \times 10^{-9} \mathrm{M}$ から $1.0 \times 10^{-5} \mathrm{M}$ の濃度範囲で $\mathrm{H}_{2} \mathrm{O}_{2}$ 濃度と $\mathrm{CL}$ 強度との 間に良好な直線関係が得られた。検量線の回帰式は $y=$ $0.364 x+5.52$, 相関係数は $r^{2}=0.996$ であった. 各 $\mathrm{H}_{2} \mathrm{O}_{2}$ において 3 回の繰り返し測定を行い, $\mathrm{H}_{2} \mathrm{O}_{2}$ の全濃度範囲 における変動係数の平均は $8.2 \%$ であった.

$\mathrm{H}_{2} \mathrm{O}_{2}$ 濃度が $4.0 \times 10^{-7} \mathrm{M}$ 以上になると, HRP 内封リポ ソーム系のほうが HRP 標準溶液系より CL 強度は増大し た. 一方, $\mathrm{H}_{2} \mathrm{O}_{2}$ 濃度が $4.0 \times 10^{-7} \mathrm{M}$ 以下では逆に HRP 標準溶液系のほうが CL 強度は大きくなり, $\mathrm{H}_{2} \mathrm{O}_{2}$ の定量 感度は約 10 倍向上した。この原因は次のように考えられ る.リポソームの内水相で CL 反応を行った場合, 添加し た $\mathrm{H}_{2} \mathrm{O}_{2}$ の一部しかリポソーム内に分配されない.したが って, HRP 内封リポソーム系の場合, CL 反応に関与する
$\mathrm{H}_{2} \mathrm{O}_{2}$ 量は $\mathrm{HRP}$ 標準溶液系より減少することが考えられ る。そのため, HRP 内封リポソーム系における $\mathrm{H}_{2} \mathrm{O}_{2}$ の 定量下限が HRP 標準溶液系より高濃度になったものと考 えられる。

$$
4 \text { 結 言 }
$$

リポソームの微小空間における HRP 触媒とする FLCL 反応を $\mathrm{H}_{2} \mathrm{O}_{2}$ の定量に応用するため, $\mathrm{H}_{2} \mathrm{O}_{2}$ の定量に適 した HRP 内封リポソームの調製条件について検討を行っ た.その結果，HRP を封入するリポソームとしては，ア ニオン性の構成成分を含み, Chol 含量は $10 \%$ で，1000 $\mathrm{nm}$ のポアサイズのフィルターで処理したリポソームが有 効であることが分かった。 また，リポソーム内水相を反応 場に利用した FL-CL 反応においても, CL 強度は $\mathrm{H}_{2} \mathrm{O}_{2}$ 濃 度に比例することから， $\mathrm{H}_{2} \mathrm{O}_{2}$ の定量に応用できることが 明らかになった。

本研究は文部科学省科学研究費補助金基盤（B）（2）(課題番号 15350038）の助成を受けて行った.

\section{文献}

1) P. Walde, S. Ichikawa: Biomol. Eng., 18, 143 (2001).

2) K. J. Hill, M. Kaszuba, J. E. Creeth, M. N. Jones: Biochim. Biophys. Acta, 1326, 37 (1997).

3) M. Blocher, P. Walde, I. J. Dunn: Biotech. Bioeng., 62, 36 (1999).

4) T. Kamidate, Y. Ishida, H. Tani, A. Ishida: Chem. Lett., 32, 402 (2003).

5) T. Segawa, A. Kakizaki, T. Kamidate, H. Watanabe: Anal. Sci., 8, 785 (1992).

6) B. B. Kim, V. V. Pisarev, A. M. Egorov: Anal. Biochem., 199, 1 (1991).

7) R. C. MacDonald, R. I. Macdonald, B. P. H. Menco, K. Takeshita, N. K. Subbarao, L. Hu: Biochem. Biophys. Acta, 1061, 297 (1991).

8) T. Segawa, H. Ishikawa, T. Kamidate, H. Watanabe: Anal. Sci., 10, 589 (1994).

9) M. C. Blok, L. L. M. Van, J. D. E. Gier: Biochim. Biophys. Acta, 464, 509 (1977). 